\title{
HUBUNGAN ANTARA POLA MAKAN IBU HAMIL DENGAN PENAMBAHAN BERAT BADAN DAN KADAR HEMOGLOBIN TRIMESTER II DI PUSKESMAS PAHANDUT KOTA PALANGKA RAYA TAHUN 2018
}

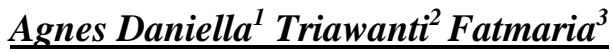 \\ 1. Pendidikan Dokter, Fakultas Kedokteran, Universitas Palangka Raya, \\ Palangka Raya, Indonesia \\ 2. Staff Pengajar Fakultas Kedokteran Universitas Palangka Raya, Palangka \\ Raya, Indonesia \\ E-mail: Agnesssss28@gmail.com
}

\begin{abstract}
ABSTRAK
Latar Belakang. Pola makan yang sehat bagi ibu hamil harus memenuhi kebutuhan ibu hamil. Pola makan yang tidak sehat dapat membuat nutrisi yang diterima tidak mencukupi kebutuhan ibu hamil dan menyebabkan beberapa dampak pada ibu hamil. Gizi makronutrien dan gizi mikronutrien yang berkaitan dengan kesehatan ibu hamil harus memenuhi kebutuhan berupa energi sebesar \pm 2500 Kkal selama kehamilan. Asupan nutrisi yang baik selama kehamilan berpengaruh terhadap penambahan berat badan ibu hamil. Rendahnya status gizi dan pola makan yang salah pada ibu hamil dapat menyebabkan berat badan kurang dan anemia.

Tujuan. Mengetahui hubungan antara pola makan sehat ibu hamil dengan penambahan berat badan dan kadar $\mathrm{Hb}$ trimester II.

Metode. Jenis penelitian yang digunakan adalah penelitian observasional analitik. Populasi penelitian ini adalah ibu hamil di Puskesmas Pahandut Kota Palangka Raya. Menggunakan teknik total sampling dimana sampel yang diambil adalah semua ibu hamil trimester II yang memenuhi kriteria inklusi pada bulan Mei-Agustus tahun 2018 yang berjumlah 89 orang. Analisis data menggunakan uji Chi Square $\left(x^{2}\right)$ dengan tingkat kemaknaan $(\alpha=0,05)$.

Hasil Penelitian. Penambahan Berat badan responden, sebanyak 28 responden $(65,1 \%)$ dengan pola makan baik dan pertambahan berat badan yang baik, tidak terdapat responden dengan pola makan baik yang pertambahan berat badannya kurang, sebanyak 15 responden (34,9\%) dengan pola makan baik dan pertambahan berat badan berlebih. Sebanyak 2 orang (7,7\%) dengan pola makan kurang dan pertambahan berat badan yang baik, sebanyak 21 orang $(80,8 \%)$ dengan pola makan kurang dan pertambahan berat badan yang kurang, sebanyak 3 orang $(11,5 \%)$ dengan pola makan kurang yang berat badannya berlebih. Sebanyak 2 orang $(10,0 \%)$ dengan pola makan buruk dan pertambahan berat badan yang baik, sebanyak 18 orang $(90,0 \%)$ dengan pola makan buruk dan tidak terdapat responden dengan pola makan buruk yang berat badannya berlebih. Kadar $\mathrm{Hb}$ Responden, 31 responden (18,8\%) dengan pola makan baik yang tidak anemia, sebanyak 12 responden $(27,9 \%)$ dengan pola makan baik yang anemia. Sebanyak 8 orang $(17,4 \%)$ dengan pola mkan kurang dan pola makan buruk yang tidak anemia dan sebanyak 38 orang $(82,6 \%)$ dengan pola makan kurang \& buruk yang mengalami anemia, dengan nilai $\mathrm{p}<0,001$.

Kesimpulan. Adanya hubungan ibu hamil pola makan dengan penambahan berat badan dan kadar $\mathrm{Hb}$ ibu hamil trimester II.
\end{abstract}

Kata kunci : Pola makan, Penambahan berat badan, Kadar Hb, Hubungan 


\section{ABSTRACT}

Background. Healthy eating patterns for pregnant women must meet the needs of pregnant women. Unhealthy eating patterns can make the nutrients received do not meet the needs of pregnant women and cause some effects on pregnant women. Macronutrient nutrition and micronutrient nutrition related to the health of pregnant women must meet the energy needs of +2500 Kcal during pregnancy. Good nutrition during pregnancy affects the weight gain of pregnant women. Low nutritional status and wrong diet in pregnant women can cause less weight and anemia.

Research purposes. Knowing the relationship between healthy eating patterns of pregnant women with weight gain and second trimester hemoglobin levels.

Method. The type of research used is analytic observational research. The population of this study were pregnant women in Pahandut Health Center, Palangka Raya City. Using total sampling technique where the samples taken were all II trimester pregnant women who met the inclusion criteria in May-August 2018 totaling 89 people. Data analysis used Chi Square $\left(x^{2}\right)$ test with significance level $(\alpha=0.05)$.

Result of research. The respondent's weight gain was 28 respondents $(65.1 \%)$ with a good diet and good weight gain, there were no respondents with a good diet with less weight gain, as many as 15 respondents (34.9\%) with a diet good and excess weight gain. As many as 2 people (7.7\%) with poor diet and good weight gain, 21 people (80.8\%) with less diet and less weight gain, as many as 3 people (11.5\%) with less eating patterns that have excess weight. As many as 2 people (10.0\%) with poor diet and good weight gain, as many as 18 people (90.0\%) with a poor diet and there were no respondents with a bad diet with excess weight. As well as the Hb level of respondents, as many as 31 respondents (18.8\%) with a good diet that is not anemic, as many as 12 respondents $(27.9 \%)$ with a good diet that is anemic. As many as 8 people $(17.4 \%)$ with poorer patterns and poor diet patterns that were not anemic and as many as 38 people (82.6\%) with poor \& poor eating patterns who experienced anemia. With $p$ value $<0.001$.

Conclusion. The existence of a relationship between pregnant women diet with weight gain and Hb levels of pregnant women in second trimester.

Keywords: diet, weight gain, Hb levels, relationships. 


\section{PENDAHULUAN}

Status gizi ibu hamil merupakan indikator yang sangat penting untuk menentukan status gizi masyarakat karena pada momentum inilah awal pembentukkan kualitas generasi mendatang. ${ }^{1}$ Pola makan dan status gizi pada ibu hamil menentukan apakah seorang ibu dapat melewati masa kehamilannya dengan baik tanpa gangguan. Pola makan yang sehat bagi ibu hamil harus memenuhi kebutuhan ibu hamil. Pola makan yang tidak sehat dapat membuat nutrisi yang diterima tidak mencukupi kebutuhan ibu hamil dan menyebabkan beberapa dampak pada ibu hamil diantaranya adalah preeklampsia, prematuritas, osteomalasia, Kekurangan Energi Kronis (KEK) dan anemia. ${ }^{2}$ Pada umumnya masalah gizi pada ibu hamil terjadi di seluruh dunia, terutama di negara berkembang (developing countries) dan pada kelompok sosio-ekonomi rendah. ${ }^{3}$

Gizi makronutrien dan gizi mikronutrien yang berkaitan dengan kesehatan ibu hamil harus memenuhi kebutuhan berupa energi sebesar \pm 2500 Kkal selama kehamilan. Asupan nutrisi yang baik selama kehamilan berpengaruh terhadap penambahan berat badan ibu hamil, rata-rata penambahan berat badan ibu hamil berkisar $>6 \mathrm{~kg}$ dengan penambahan antara $10-15 \mathrm{~kg}$ yaitu $1-2 \mathrm{~kg}$ pada trimester I dan selebihnya pada trimester II dan III. Mulai trimester II akan terjadi penambahan berat badan dan pelebaran tubuh yang terlihat sampai pada trismester III dengan rata - rata pertambahan berat badan adalah $0,4-0,5 \mathrm{~kg} / \mathrm{minggu}^{2}$ Lingkar lengan Atas (LILA) pada ibu hamil juga bertambah pada masa kehamilan, ambang batas LILA pada wanita hamil adalah $23,5 \mathrm{~cm}$ dan apabila $<23,5$ ibu hamil beresiko KEK. ${ }^{4}$ Asupan nutrisi juga berpengaruh dengan kadar Hemoglobin $(\mathrm{Hb})$, penurunan kadar $\mathrm{Hb}$ dalam darah pada kehamilan dapat mencapai <11gr/dL. ${ }^{5,6}$ Menurut World Health Organization (WHO), persentase tertinggi penyebab kematian ibu adalah perdarahan dan infeksi, yang dapat disebabkan anemia dan KEK. Di berbagai negara kejadian ini berkisar $<10 \%$ sampai hampir $60 \% .^{2}$ Menurut hasil Pemantauan Status Gizi (PSG) pada tahun 2017 yang dilaksanakan di 514 kabupaten dan kota di 34 Provinsi, Ibu hamil yang memiliki risiko KEK sebesar 16,2\%, ibu hamil yang mengalami defisit energi sebesar 53,9\%, sedangkan yang defisit protein sebesar $51,9 \%$ dan penderita anemia sebesar $70 \% .^{7,8}$ Menurut Profil Kesehatan dari Dinas Kesehatan Kota Palangkaraya (2016) terdapat ibu hamil yang mengalami anemia dengan $\mathrm{Hb}<11 \mathrm{gr} / \mathrm{dL}$ sebesar 2,35\% dan ibu hamil KEK dengan LILA $<23,5 \mathrm{~cm}$ sebesar $7,73 \%{ }^{1}$ Berdasarkan data survei pendahuluan yang dilakukan pada 6 maret 2018 ibu hamil terbanyak yang mengalami anemia dan KEK pada tahun 2017 di Puskesmas Pahandut, dari 896 kunjungan ibu hamil yaitu sebanyak 106 orang dengan total presentase $11 \%$ mengalami anemia dan sebanyak 18 orang dengan total presentase $80 \%$ mengalami KEK.

Rendahnya status gizi dan pola makan yang salah pada ibu hamil dapat menyebabkan berat badan kurang dan anemia. Berat badan yang kurang dan anemia defisiensi zat besi kasusnya jarang menyebabkan kematian, namun dampaknya 
terhadap manusia sangat signifikan. ${ }^{9,10}$ Berdasarkan penelitian Arsy Prawita,dkk (2015), faktor-faktor yang mempengaruhi KEK antara lain: asupan makanan yang kurang, penyakit kronis, tingkat pendidikan, tinggi badan ibu, ibu tidak bekerja, posisi ibu dalam rumah tangga, lingkungan rumah di pedesaan, ibu hamil tidak dalam ikatan perkawinan, serta status ekonomi. ${ }^{11}$ Sedangkan, menurut Abidah,dkk (2013) faktor - faktor yang berpengaruh terhadap kejadian anemia pada ibu hamil diantaranya yaitu pengetahuan, frekuensi Antenatal Care (ANC), status ekonomi dan status gizi. $^{12}$ Berdasarkan penelitian terebut, diketahui jika asupan energi, status gizi, dan frekuensi ANC berpengaruh terhadap kondisi ibu selama masa kehamilan.

Pengawasan selama kehamilan diperlukan untuk memantau kesehatan ibu dan janin. ANC perlu dilakukan secara rutin oleh ibu hamil untuk memantau status gizi berupa penambahan berat badan, LILA dan kadar $\mathrm{Hb}$. Pemeriksaan berat badan, LILA dan $\mathrm{Hb}$ adalah yang terpenting untuk dilakukan. Pertambahan berat badan, LILA dan kualitas kadar $\mathrm{Hb}$ ibu selama kehamilan berhubungan dengan pola makan ibu selama kehamilan. Masalah tersebut berhubungan langsung dengan kurangnya konsumsi makanan yang mengandung kalori, protein dan zat besi atau adanya gangguan penyerapan nutrisi dalam tubuh. ${ }^{10}$

Pola makan ibu hamil mempengaruhi status gizi ibu hamil, hal ini berhubungan langsung dengan penambahan berat badan dan kadar Hb ibu selama masa kehamilan. Berdasarkan pemaparan diatas, maka perlu dilakukan suatu penelitian yang bertujuan untuk mengetahui "Hubungan Antara Pola
Makan Ibu Hamil Dengan Penambahan

Berat Badan Dan Kadar Hemoglobin Trimester II Di Puskesmas Pahandut Kota Palangka Raya Tahun 2018".

\section{METODOLOGI PENELITIAN Jenis dan Rancangan Penelitian}

Jenis penelitian ini adalah observasional analitik yaitu penelitian yang menjelaskan adanya hubungan variable melalui pengujian hipotesa.

Sedangkan pelaksanaan penelitian dengan metode survey dan hasil rekam medik. Berdasarkan waktu penelitian rancangan penelitian ini adalah cross sectional.

\section{Populasi Penelitian}

Populasi target dalam penelitian ini adalah semua ibu hamil yang memeriksakan berat badan dan kadar $\mathrm{Hb}$ pada trimester II di Puskesmas Pahandut Palangka Raya pada bulan Juni-Agustus tahun 2018 yang berjumlah 89 orang.

\section{Sampel dan Teknik Pengambilan Sampel}

Pada penelitian ini sampel diambil dengan teknik total sampling dimana sampel yang diambil adalah semua ibu hamil trimester II yang memenuhi kriteria inklusi pada bulan JuniAgustus tahun 2018 yang berjumlah 89 orang.

\section{Kriteria Pemilihan (Inklusi dan Eklusi) Kriteria Inklusi}

Kriteria inklusi merupakan kriteria dimana subyek penelitian mewakili sampel penelitian yang memenuhi syarat sebagai sampel. Pada penelitian ini yang memenuhi kriteria sampel adalah sebagai berikut:

a. Bersedia menjadi responden penelitian. 
b. Ibu hamil trimester II yang bisa baca tulis.

c. Ibu hamil trimester II yang melakukan pemeriksaan berat badan dan kadar $\mathrm{Hb}$ di Puskesmas Pahandut Kota Palangka Raya pada tahun 2018.

d. Ibu hamil tidak memiliki penyakit akut maupun kronis pada saat hamil, tidak mengalami preeklamsi-eklamsi.

e. Tidak hamil kembar.

\section{Kriteria Eksklusi}

Kriteria Eksklusi merupakan karakteristik atau faktor yang menyebabkan subyek yang memenuhi kriteria inklusi tidak dapat ikut dalam penelitian. Pada penelitian ini yang masuk dalam kriteria eksklusi adalah:
a. Tidak bersedia menjadi responden penelitian.
b. Data rekam medik tidak lengkap.
c. Dalam keadaan sakit.

\section{Variabel Penelitian}

Variabel adalah karakteristik subyek penelitian yang berubah dari satu subyek ke subyek lain. Variabel harus diletakkan dalam konteks penelitian. Menurut fungsinya dalam konteks penelitian, khususnya dalam hubungan antar-variabel, terdapat beberapa jenis variable yaitu variabel bebas (independent) dan variabel tergantung (dependent). ${ }^{27}$

Variabel terikat: Penambahan berat badan dan kadar Hb ibu hamil

Variabel bebas : Pola makan ibu hamil

\section{Definisi Operasional}

\section{Pola Makan}

\section{Penilaian Baik:}

- Jenis makanan baik

- Frekuensi makan baik

- Jumlah energi baik

\section{Penilaian Kurang :}

Salah satu dari jenis makanan, frekuensi makan atau jumlah energi kurang

\section{Penilaian Buruk :}

Jenis makanan, frekuensi makan dan jumlah energi dengan kategori kurang atau tidak baik (kurang dari 2 aspek)

Hasil rekam medis mengenai hasil penambahan berat badan dan kadar $\mathrm{Hb}$ pada responden.

\section{Penambahan Berat Badan}

Penambahan Berat Badan Baik :
a. IMT Kurang : 0.44-0.58 kg/Minggu
b. IMT Normal : $0.35-0.50 \mathrm{~kg} / \mathrm{Ming} g \mathrm{u}$
c. IMT Overweight: $0.23-0.33 \mathrm{~kg} /$ Minggu
d. IMT Obesitas : 0.17-0.27 kg/ Minggu

Penambahan Berat Badan Kurang :

a. IMT Kurang : $<0.44 \mathrm{~kg} /$ Minggu

b. IMT Normal : $<0.35 \mathrm{~kg} /$ Minggu

c. IMT Overweight : $<0.23 \mathrm{~kg} /$ Minggu

d. IMT Obesitas : $<0.17 \mathrm{~kg} /$ Minggu

Penambahan Berat Badan Berlebih :
a. IMT Kurang : > $0.58 \mathrm{~kg} /$ Minggu
b. IMT Normal : $>0.50 \mathrm{~kg} /$ Minggu
c. IMT Overweight : $>0.33 \mathrm{~kg} /$ Minggu
c. IMT Obesitas : > $0.27 \mathrm{~kg} /$ Minggu

\section{Kadar Hb}

Tidak anemia $:(\mathrm{Hb} \geq 11.0 \mathrm{mg} / \mathrm{dL})$

Anemia $\quad:(\mathrm{Hb}<11.0 \mathrm{mg} / \mathrm{dL})$

\section{Instrumen Penelitian}

Dalam prosedur pengambilan dan pengumpulan data, peneliti melakukan tahaptahap sebagai berikut:

a.Data primer diperoleh dari: 
1. Hasil wawancara langsung dengan

b. IMT Normal : $<0.35 \mathrm{~kg} /$ Minggu responden meliputi pola makan pada

c. IMT Overweight : $<0.23 \mathrm{~kg} /$ Minggu responden.

d. IMT Obesitas : < $0.17 \mathrm{~kg} /$ Minggu

Pola Makan

Penilaian baik :

Penambahan Berat Badan Berlebih :

a. Jenis makanan : Bila menu makanan terdiri

a. IMT Kurang : > $0.58 \mathrm{~kg} /$ Minggu

b. IMT Normal : > $0.50 \mathrm{~kg} /$ Minggu dari makanan pokok, lauk, sayur, buah, susu, gula \& minyak.

b. Frekuensi Makanan : 3 Kali/Hari.

c. Jumlah makanan : Total energi 2500 $\mathrm{Kkal} / \mathrm{hari}$.

\section{Penilaian Kurang :}

c. IMT Overweight : $>0.33 \mathrm{~kg} /$ Minggu

c. IMT Obesitas : > $0.27 \mathrm{~kg} /$ Minggu

Penilaian menggunakan timbangan smic, penilaian penambahan berat badan dilakukan 3 minggu setelah penilaian berat badan pertama kali responden diwawancara.

\section{Kadar Hb}

a. Jenis Makanan : Bila menu makanan kurang (salah satu) dari jenis makanan (makanan pokok, lauk, sayur, buah, susu, gula \& minyak).

b. Frekuensi Makanan : Bila makanan memenuhi $=2$ Kali $/$ Hari.

c. Jumlah makanan : Total energi 1500 - 2000 $\mathrm{Kkal} / \mathrm{hari}$.

Penilaian buruk :

a. Jenis makanan : Bila menu makanan kurang (dua aspek atau lebih) dari jenis makanan (makanan pokok, lauk, sayur, buah, susu, gula \& minyak).

b. Frekuensi Makanan : 1 Kali/Hari.

c. Jumlah makanan : Total energi $<1500$ $\mathrm{Kkal} / \mathrm{hari}$.

2. Hasil rekam medis mengenai hasil penambahan berat badan dan kadar $\mathrm{Hb}$ pada responden.

\section{Penambahan Berat Badan} Penambahan Berat Badan Baik :

a. IMT Kurang : 0.44-0.58 kg/Minggu

b. IMT Normal : 0.35-0.50 kg/ Minggu

c. IMT Overweight: $0.23-0.33 \mathrm{~kg} /$ Minggu

d. IMT Obesitas : 0.17-0.27 kg/ Minggu

Penambahan Berat Badan Kurang :

a. IMT Kurang : < 0.44 kg/Minggu

Tidak anemia $:(\mathrm{Hb} \geq 11.0 \mathrm{mg} / \mathrm{dL})$

Anemia $\quad:(\mathrm{Hb}<11.0 \mathrm{mg} / \mathrm{dL})$

Penilaian $\mathrm{Hb}$ dilakukan di laboraturium

Puskesmas Pahandut dengan menggunakan haemometer sahli.

b. Data sekunder diperoleh dari:

Mengajukan surat ijin penelitian kebidang akademik FK UPR yang akan direkomendasikan ke Dinas Kesehatan Kota Palangka Raya untuk mengeluarkan ijin pengambilan data berupa data penambahan berat badan dan kadar $\mathrm{Hb}$ ibu hamil yang melakukan kunjungan ANC di Puskesmas Pahandut Kota Palangka Raya bulan JuniAgustus tahun 2018.

\section{HASIL PENELITIAN}

Pengambilan data dilaksanakan di Puskesmas Pahandut, Kota Palangka Raya, Kalimantan Tengah selama bulan Juni Agustus 2018 dengan jumlah sampel sebanyak 89 orang ibu hamil trimester II.

Pengambilan data yang dilaksanakan di puskesmas dilakukan setiap hari kecuali hari libur dan adanya jadwal perkuliahan yaitu 
dari jam masuk kerja hingga pulang, mulai pukul 08.00 hingga pukul 12.00 wib.

Pengumpulan data responden dilakukan dengan menggunakan kuesioner yang telah disediakan oleh peneliti yang kemudian dilakukannya wawancara terhadap responden. Dalam penelitian ini responden penelitian adalah ibu hamil trimester II yang memeriksakan kesehatan di puskesmas Pahandut.

\section{A. Analisis Univariat}

\section{Gambaran Umur Responden}

Data distribusi umur responden disajikan pada tabel 5.1 :

Tabel 5.1 Distribusi Umur Responden

\begin{tabular}{ccc}
\hline $\begin{array}{c}\text { Umur } \\
\text { (Tahun) }\end{array}$ & $\begin{array}{c}\text { Frekuensi } \\
(\mathbf{n})\end{array}$ & \% \\
\hline $18-24$ & 23 & 25,8 \\
$25-29$ & 26 & 29,2 \\
$30-34$ & 22 & 24,7 \\
$35-40$ & 15 & 16,9 \\
$>40$ & 3 & 3,4 \\
\hline Total & 89 & 100.0 \\
\hline \multicolumn{4}{c}{ Dari hasil } & analisis & responden \\
berdasarkan distribusi umur, diketahui dari 89 \\
responden dengan umur termuda & 18 tahun \\
dan tertua 43 tahun.
\end{tabular}

2. Gambaran Berat Badan Responden Sebelum Masa Kehamilan

Data distribusi berat badan sebelum masa kehamilan responden disajikan pada tabel 5.2:

Tabel 5.2 Distribusi Berat Badan Sebelum Masa Kehamilan Responden

\begin{tabular}{|c|c|c|c|}
\hline $\begin{array}{l}\text { Berat } \\
(\mathrm{Kg})\end{array}$ & Badan & $\begin{array}{l}\text { Frekuensi } \\
\text { (n) }\end{array}$ & $\%$ \\
\hline $39-49,9$ & & 35 & 39,3 \\
\hline $50-59,9$ & & 35 & 39,3 \\
\hline $60-69,9$ & & 13 & 14,6 \\
\hline$>70$ & & 6 & 6,7 \\
\hline Total & & 89 & 100.0 \\
\hline
\end{tabular}

Dari hasil analisis berdasarkan distribusi berat badan sebelum masa kehamilan responden, diketahui responden dengan berat terendah $39 \mathrm{Kg}$ dan berat tertinggi $74 \mathrm{Kg}$.

\section{Gambaran Tinggi Badan Responden}

Data distribusi tinggi badan responden disajikan pada tabel 5.3 :

Tabel 5.3 Distribusi Tinggi Badan Responden

\begin{tabular}{|c|c|c|}
\hline $\begin{array}{l}\text { Tinggi Badan } \\
(\mathrm{Cm})\end{array}$ & $\begin{array}{l}\text { Frekuensi } \\
\text { (n) }\end{array}$ & $\%$ \\
\hline $140-149,9$ & 23 & 25,8 \\
\hline $150-159,9$ & 54 & 60,7 \\
\hline$>160$ & 12 & 13,5 \\
\hline Total & 89 & 100.0 \\
\hline
\end{tabular}
badan responden, diketahui responden dengan tinggi badan terendah $144 \mathrm{Cm}$ dan tertinggi 162 $\mathrm{Cm}$.

\section{Gambaran IMT Responden}

Data distribusi IMT responden disajikan pada tabel 5.4 :

Tabel 5.4 Distribusi IMT Responden

IMT Frekuensi \%

(n)

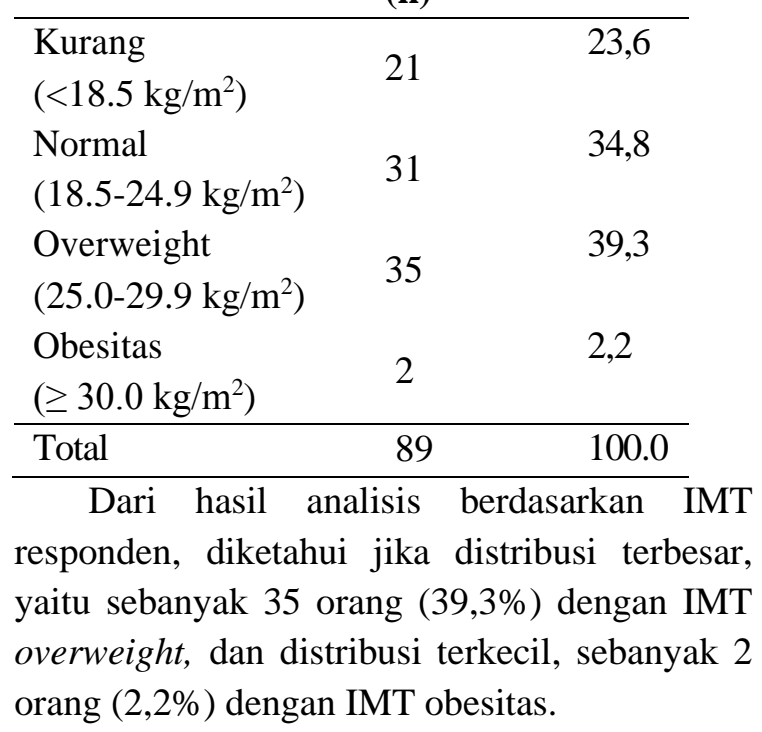

\section{Gambaran Kehamilan Responden}


Data distribusi kehamilan responden disajikan pada tabel 5.5 :

Tabel 5.5 Distribusi Kehamilan Responden

\begin{tabular}{lll}
\hline Kehamilan & $\begin{array}{l}\text { Frekuensi } \\
(\mathbf{n})\end{array}$ & $\mathbf{\%}$ \\
\hline 1 & 18 & 20,2 \\
2 & 30 & 33,7 \\
$>2$ & 41 & 46,1 \\
\hline Total & 89 & 100.0 \\
\hline
\end{tabular}

Dari hasil analisis berdasarkan kehamilan responden, diketahui jika distribusi terbesar, yaitu sebanyak 41 orang $(46,1 \%)$ dengan kehamilan lebih dari dua kali dan distribusi terkecil sebanyak 18 orang $(20,2 \%)$ dengan kehamilan pertama.

\section{Gambaran Tingkat Pendidikan}

Responden

Data distribusi tingkat pendidikan responden disajikan pada tabel 5.6 :

Tabel 5.6 Distribusi Tingkat Pendidikan Responden

\begin{tabular}{lll}
\hline $\begin{array}{l}\text { Tingkat } \\
\text { Pendidikan }\end{array}$ & $\begin{array}{l}\text { Frekuensi } \\
\text { (n) }\end{array}$ & \% \\
\hline Tidak Sekolah & 9 & 10,1 \\
SD & 43 & 48,3 \\
SMP & 21 & 23,6 \\
SMA & 14 & 15,7 \\
S1 & 2 & 2,2 \\
\hline Total & 89 & 100.0 \\
\hline
\end{tabular}

Dari hasil analisis berdasarkan tingkat pendidikan responden, diketahui jika distribusi terbesar, yaitu sebanyak 43 orang $(48,3 \%)$ responden dengan pendidikan SD dan distribusi terkecil sebanyak 2 orang $(2,2 \%)$ dengan pendidikan S1.

\section{Gambaran Pekerjaan Responden}

Data distribusi pekerjaan responden disajikan pada tabel 5.7:

Tabel 5. Distribusi Pekerjaan Responden

\begin{tabular}{lll}
\hline Pekerjaan & $\begin{array}{l}\text { Frekuensi } \\
\text { (n) }\end{array}$ & \% \\
\hline IRT & 56 & 62,9 \\
Wiraswasta & 30 & 33,7 \\
Pegawai & 3 & 3,4 \\
\hline Total & 89 & 100.0 \\
\hline
\end{tabular}

Dari hasil analisis berdasarkan pekerjaan responden, diketahui jika distribusi terbesar, yaitu sebanyak 56 orang $(62,9 \%)$ responden adalah IRT dan distribusi terkecil sebanyak 2 orang $(3,4 \%)$ adalah pegawai.

\section{Gambaran Pola Makan}

Data distribusi pola makan responden disajikan pada tabel 5.8:

Tabel 5.8 Distribusi Pola Makan Responden

Pola Makan Frekuensi $\%$

(n)

\begin{tabular}{ccc}
\hline Baik & 43 & 48,3 \\
Kurang & 26 & 29,2 \\
Buruk & 20 & 22,5 \\
\hline Total & 89 & 100.0 \\
\hline
\end{tabular}

Dari hasil analisis berdasarkan pola makan responden, diketahui jika distribusi terbesar, yaitu 43 orang $(48,3 \%)$ responden dengan pola makan baik dan distribusi terkecil sebanyak 20 orang $(22,5 \%)$ responden dengan pola makan buruk.

\section{Gambaran Penambahan Berat Badan}

Data distribusi penambahan berat badan responden disajikan pada tabel 5.9 :

Tabel 5.9 Distribusi Penambahan Berat Badan Responden

\begin{tabular}{ccc}
\hline $\begin{array}{c}\text { Penambahan } \\
\text { Berat Badan } \\
(\mathbf{K g})\end{array}$ & $\begin{array}{c}\text { Frekuensi } \\
(\mathbf{n})\end{array}$ & $\%$ \\
\hline Baik & 32 & 36,0 \\
Kurang & 39 & 43,8 \\
Berlebih & 18 & 20,2 \\
\hline
\end{tabular}




\begin{tabular}{l} 
Total \\
\hline Dari hasil analisis berdasarkan pola makan \\
responden, diketahui jika distribusi terbesar, \\
yaitu 39 orang $(43,8 \%)$ \\
penambahan berat badan kurang dan distribusi \\
terkecil sebanyak 18 orang $(20,2 \%)$ responden \\
dengan penambahan berat badan berlebih.
\end{tabular}

\section{Gambaran Kadar Hb}

Data distribusi kadar $\mathrm{Hb}$ responden disajikan pada tabel 5.10 :

\section{Tabel 5.10 Distribusi Kadar Hb Responden}

\begin{tabular}{|c|c|c|}
\hline Kadar Hb & Frekuensi (n) & $\%$ \\
\hline $\begin{array}{c}\text { Tidak Anemia } \\
(\mathrm{Hb} \geq 11.0 \\
\mathrm{mg} / \mathrm{dL})\end{array}$ & 39 & 43,8 \\
\hline $\begin{array}{c}\text { Anemia } \\
(\mathrm{Hb}<11.0 \\
\mathrm{mg} / \mathrm{dL})\end{array}$ & 50 & 58,2 \\
\hline Total & 89 & 100.0 \\
\hline
\end{tabular}

Dari hasil analisis berdasarkan pola makan responden, diketahui jika distribusi terbesar, yaitu 50 orang $(58,2 \%)$ responden dengan anemia dan distribusi terkecil sebanyak 39 orang $(43,8 \%)$ responden tidak anemia.

\section{B. Analisis Bivariat}

\section{Hubungan Pola Makan dengan Penambahan Berat Badan Ibu Hamil Trimester II}

Gambaran hubungan pola makan dengan penambahan berat badan ibu hamil trimester II pada tabel 5.11 :

Tabel 5.11 Distribusi Penambahan Berat Badan Responden berdasarkan pola makan

\begin{tabular}{|c|c|c|c|c|c|c|c|}
\hline \multirow{3}{*}{ Kateegori } & \multicolumn{6}{|c|}{ Berat Badan (Kg) } & \multirow{3}{*}{$\begin{array}{l}\text { Nilai } \\
p\end{array}$} \\
\hline & \multicolumn{2}{|c|}{ Baik } & \multicolumn{2}{|c|}{ Kurang } & \multicolumn{2}{|c|}{$\begin{array}{l}\text { Berlebi } \\
\mathrm{h}\end{array}$} & \\
\hline & $\mathrm{n}$ & $\%$ & $\mathrm{n}$ & $\%$ & $\mathrm{n}$ & $\%$ & \\
\hline Baik & 28 & 65 & 0 & 0 & 1 & 34 & 0,000 \\
\hline o & & 1 & & 0 & 5 & ,9 & \\
\hline 1 & & $\%$ & & $\%$ & & $\%$ & \\
\hline Kuran & 2 & 7 & 21 & 8 & 3 & 11 & \\
\hline
\end{tabular}

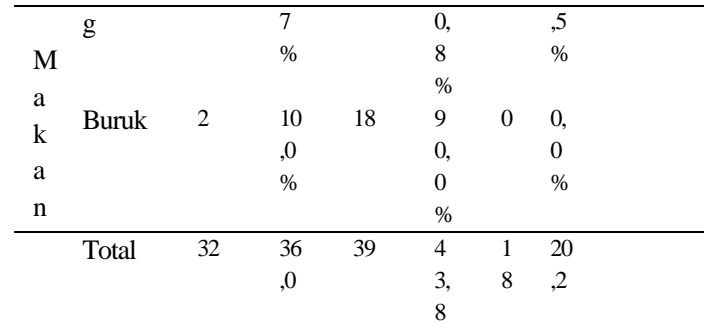

Pola makan pasien diketahui dengan menggunakan kuesioner Food Recall (3x repeat 24-hours) dan dihitung menggunakan aplikasi NutriSurvey. Formulir diisi oleh peneliti sesuai dengan jawaban yang diberikan oleh responden. Food Recall dilakukan sebanyak 3 kali untuk mendapatkan pola makanan yang dikonsumsi responden. Data yang didapat kemudian dimasukkan kedalam NutriSurvey.

Berdasarkan tabel 5.11 diketahui jika, 28 responden $(65,1 \%)$ dengan pola makan baik dan pertambahan berat badan yang baik, tidak terdapat responden dengan pola makan baik yang pertambahan berat badannya kurang, sebanyak 15 responden $(34,9 \%)$ dengan pola makan baik dan pertambahan berat badan berlebih. Sebanyak 2 orang $(7,7 \%)$ dengan pola makan kurang dan pertambahan berat badan yang baik, sebanyak 21 orang $(80,8 \%)$ dengan pola makan kurang dan pertambahan berat badan yang kurang, sebanyak 3 orang $(11,5 \%)$ dengan pola makan kurang yang berat badannya berlebih. Sebanyak 2 orang $(10,0 \%)$ dengan pola makan buruk dan pertambahan berat badan yang baik, sebanyak 18 orang $(90,0 \%)$ dengan pola makan buruk dan tidak terdapat responden dengan pola makan buruk yang berat badannya berlebih.

Uji statistik yang dilakukan adalah uji Chisquare pada tingkat kepercayaan $95 \%(\alpha=0,05)$. Hasil interpretasi data pada tabel 3X3 ini terdapat nilai expected yang kurang dari lima, tetapi masih dapat digunakan karena jumlah cell dengan frekuensi harapan yang kurang dari 5 tidak lebih dari $20 \%(11,1 \%)$. Berdasarkan hasil 
analisis diperoleh ( $\mathrm{p}$-value $<0,05)$ yang berarti terdapat hubungan antara pola makan dengan penambahan berat badan ibu hamil trimester II di Puskesmas Pahandut.

\section{Hubungan Pola Makan dengan Kadar Hb Ibu Hamil Trimester II}

Gambaran hubungan pola makan dengan kadar $\mathrm{Hb}$ ibu hamil trimester II pada tabel 5.12 :

Tabel 5.12 Distribusi Kadar Hb Responden berdasarkan pola makan

\begin{tabular}{|c|c|c|c|c|c|c|}
\hline & & & $\mathrm{Hb}$ & & & Nilai \\
\hline & & $\begin{array}{l}\text { Tic } \\
\text { An }\end{array}$ & & & & \\
\hline & & $\mathrm{n}$ & $\%$ & $\mathrm{n}$ & $\%$ & \\
\hline Pola & Baik & 3 & 34,8 & 12 & $13,5 \%$ & 0,00 \\
\hline Maka & & 1 & $\%$ & & & 0 \\
\hline $\mathrm{n}$ & Kuran & 8 & $9,0 \%$ & 18 & $20,2 \%$ & \\
\hline & g & & & & & \\
\hline & Buruk & 0 & $0,0 \%$ & 20 & $40,0 \%$ & \\
\hline & Total & 3 & 43,8 & 5 & 56,2 & \\
\hline & & 9 & $\%$ & 0 & $\%$ & \\
\hline
\end{tabular}

Tabel 5.13 Hasil Analisis Chi- Square Kadar Hb Responden berdasarkan pola makan

\begin{tabular}{|c|c|c|c|c|c|c|}
\hline & & \multicolumn{4}{|c|}{ Kadar $\mathrm{Hb}$} & Nila \\
\hline & \multirow[t]{2}{*}{ Kategori } & \multicolumn{2}{|c|}{$\begin{array}{l}\text { Tidak } \\
\text { Anemia }\end{array}$} & \multicolumn{2}{|c|}{ Anemia } & \\
\hline & & $\mathrm{n}$ & $\%$ & $\mathrm{~N}$ & $\%$ & \\
\hline \multirow{6}{*}{$\begin{array}{l}\mathrm{P} \\
\mathrm{ol} \\
\mathrm{a} \\
\mathrm{M} \\
\mathrm{ak} \\
\mathrm{an}\end{array}$} & \multirow[t]{2}{*}{ Baik } & 3 & 18,8 & 12 & 27,9 & 0,00 \\
\hline & & 1 & $\%$ & & $\%$ & 0 \\
\hline & \multirow{4}{*}{$\begin{array}{l}\text { Kurang } \\
\text { \& Buruk }\end{array}$} & \multirow[t]{4}{*}{8} & \multirow{4}{*}{$\begin{array}{l}17,4 \\
\%\end{array}$} & \multirow[t]{4}{*}{38} & \multirow{4}{*}{$\begin{array}{l}82,6 \\
\%\end{array}$} & \\
\hline & & & & & & \\
\hline & & & & & & \\
\hline & & & & & & \\
\hline & \multirow[t]{2}{*}{ Total } & 3 & 43,8 & 5 & 56,2 & \\
\hline & & 9 & $\%$ & 0 & $\%$ & \\
\hline
\end{tabular}

Berdasarkan tabel 5.13 diketahui jika, 31 responden $(18,8 \%)$ dengan pola makan baik yang tidak anemia, sebanyak 12 responden (27,9\%) dengan pola makan baik yang anemia. Sebanyak 8 orang $(17,4 \%)$ dengan pola mkan kurang dan pola makan buruk yang tidak anemia dan sebanyak 38 orang $(82,6 \%)$ dengan pola makan kurang \& buruk yang mengalami anemia.

Uji statistik yang dilakukan adalah uji $C h i-$ square pada tingkat kepercayaan $95 \%(\alpha=0,05)$. Hasil interpretasi data pada tabel $2 \mathrm{X} 3$ ini terdapat nilai expected yang kurang dari lima, tetapi masih dapat digunakan dengan pengabungan antara pola makan kurang dan pola makan buruk sehingga nilai expected dapat memenuhi syarat. Berdasarkan hasil analisis diperoleh (p-value < 0,05 ) yang berarti terdapat hubungan antara pola makan dengan penambahan berat badan ibu hamil trimester II di Puskesmas Pahandut.

\section{PEMBAHASAN}

1. Hubungan Pola Makan dengan Penambahan Berat Badan Ibu Hamil Trimester II

Pada penelitian ini pola makan ibu hamil di Puskesmas Pahandut dikategorikan menjadi dua, yaitu baik jika jenis, frekuensi dan kebutuhan energi dikategorikan baik, dikategorikan kurang jika salah satu dari jenis makanan, frekuensi makan atau jumlah energi kurang dan kategori buruk jenis makanan, frekuensi makan tidak baik atau jumlah energi (kurang dari 2 aspek). Berdasarkan tabel 5.8, diketahui bahwa terdapat 43 orang $(48,3 \%)$ dengan pola makan baik, 26 orang $(29,2 \%)$ dengan pola makan kurang dan 20 orang $(22,5 \%)$ dengan pola makan buruk. Secara keseluruhan sebagian besar ibu hamil pola makannya baik, tetapi pola makan ibu yang tidak baik (kurang dan buruk) cukup banyak didapati, hal ini disebabkan karena ibu hamil kurang memperhatikan pemenuhan makanannya sendiri yang akan berdampak pada keadaan gizi ibu hamil ${ }^{1,2}$ 
Berdasarkan hasil bivariat dengan menggunakan uji Chi-Square diperoleh hasil yang menunjukkan ada hubungan yang signifikan antara pola makan dengan penambahan berat badan pada ibu hamil trimester II di Puskesmas Pahandut, dengan nilai $p=<0,001$. Pada tabel 5.11 ditemukan ibu hamil yang penambahan berat badannya kurang dan buruk namun pola makannya baik, ibu hamil yang penambahan berat badannya baik dan berlebih dengan pola makan kurang, serta ibu hamil dengan berat badan yang baik dengan pola makan buruk. Kondisi seperti ini perlu diperhatikan oleh ibu hamil karena akan berdampak pada kesehatan ibu dan janinnya. Ibu yang pola makannya kurang dapat diindikasikan bahwa ibu tidak tercukupi kebutuhan nutrisinya sehingga berpeluang memiliki status gizi kurang. Jika kebiasaan ini berlangsung lama maka ibu hamil akan berisiko mengalami preeklampsia, prematuritas, osteomalasia, KEK dan anemia. ${ }^{2}$ Hal ini sesuai dengan penelitian Hariati dkk (2016) yang menyatakan bahwa pola makan berhubungan dengan penambahan berat badan. ${ }^{31}$

Penambahan berat badan ibu hamil berhubungan dengan kondisi kesehatan ibu hamil. Berdasarkan tabel 5.1 diketahui jika sebagian ibu hamil pada umur yang beresiko. Umur yang beresiko dalam kehamilan adalah kurang dai 20 tahun dan lebih dari 35 tahun. Terlalu muda melahirkan dan terlalu tua melahirkan dapat membahayakan kehidupan ibu dan anak. Hal ini dapat mengakibatkan timbulnya berbagai masalah pada kehamilan. Hal ini sesuai dengan penelitian Fajrina (2016) bahwa terdapat hubungan umur ibu hamil dengan penambahan berat badan saat kehamilan. $^{32}$
Berat badan dan tinggi berhubungan dengan IMT. Dimana IMT adalah sebagai salah satu penentu status gizi ibu hamil. Pada tabel 5.3 diketahui jika terdapat ibu hamil dengan tinggi badan yang kurang dari $145 \mathrm{~cm}$, dimana ibu dengan tinggi badan kurang dari $145 \mathrm{~cm}$ kecendrungan memiliki panggul sempit dan berisiko mengalami KEK. sebaiknya berat badan terkontrol tidak lebih dari $12,5 \mathrm{~kg}$ selama kehamilan agar terhindar dari resiko panggul sempit, hal ini yang menyebabkan asupan pada ibu hamil yang tinggi badannya kurang tidak terpenuhi dengan baik di bandingkan dengan ibu hamil yang ukuran tinggi badan lebih dari $145 \mathrm{~cm}^{33}$

Penambahan berat badan ibu selama kehamilan akan berbeda-beda karena ditentukan oleh IMT ibu sendiri. Pada Tabel 5.4 diketahui jika terdapat ibu hamil dengan IMT yang tidak normal, hal ini berpengaruh terhadap penambahan berat badan ibu saat masa kehamilan. Berat badan ibu hamil yang diukur setiap kali pemeriksaan merupakan cara yang paling umum dilakukan, dikarenakan penambahan berat badan menjadi tolak ukur untuk melihat pertumbuhan janin. Menurut Arisman (2009) ibu hamil dengan IMT kurang (29) dianjurkan menaikan berat badannya $7 \mathrm{Kg}$ saja. Laju pertambahan berat badan selama kehamilan harus selalu dipantau tiap semesternya. ${ }^{34}$ Pada trimester I biasanya nafsu makan ibu kurang dikarenakan adanya rangsangan mual dan muntah, sehingga kemungkinan ibu hamil akan kekurangan nutrisi yang mempengaruhi berat badan ibu atau berat bada ibu hanya bertambah sedikit. Pada trimester II kondisi ibu mulai stabil, ibu hamil sudah mulai terbiasa dengan kehamilannya, rasa mual dan muntah tidak ada pada trimester ini sehingga nafsu makan ibu cenderung baik dan 
berat badan ibu pun bertambah secara nyata, tetapi menurut Istiany dan Rusilanti (2013) mengatakan pada trimester ini harus berhatihati dalam mengatur pola makan, karena kenaikan berat badan yang dianjurkan adalah $0.5 \mathrm{Kg}$ tiap minggunya. ${ }^{35}$

Pada tabel 5.5 diketahui bahwa lebih banyak ibu hamil dengan kehamilan lebih dari 2 kali. Kehamilan ibu sebelumnya juga berpengaruh terhadap kehamilan berikutnya. Ibu hamil yang terlalu sering melahirkan dan terlalu dekat jarak kehamilannya berpengaruh terhadap status gizi ibu hamil. Hal ini sesuai dengan penelitian Fajrina (2016) bahwa penambahan berat badan ibu hamil berhubungan dengan kehamilan sebelumnya. ${ }^{32}$

Pola makan yang baik bagi ibu hamil harus memenuhi kebutuhan ibu hamil. Berdasarkan tabel 5.6 diketahui bahwa lebih banyak ibu dengan tingkat pendidikan kurang. Ibu hamil dengan pola makan yang kurang dan buruk dapat mengindikasikan jika tingkat pengetahuan ibu hamil terhadap kebutuhan gizi kurang. Hal ini sesuai dengan penelitian RAJ. Budiani Retnaningsih (2010) bahwa tingkat pengetahuan ibu hamil terhadap kebutuhan gizi berhubungan dengan status gizi ibu hamil. Pemberian pengetahuan tentang status gizi ibu hamil adalah bagian dari upaya untuk mengoptimalkan kesehatan ibu hamil. ${ }^{33}$

Adanya ibu yang memiliki pola makan kurang dan buruk dapat diindikasikan bahwa ibu memiliki kebiasaan makan yang sama seperti kondisi sebelum hamil, padahal kebutuhan makanan ibu hamil 3 kali lipat lebih banyak dari sebelumnya. Berdasarkan data pada tabel 5.7, diketahui bahwa lebih banyak ibu hamil yang sehari- harinya sebagai IRT. Hal ini dapat diindikasikan bahwa aktifitas fisik yang dilakukan sebagai seorang IRT cenderung lebih rendah daripada ibu yang bekerja di luar rumah dengan kapasitas pekerjaan yang membutuhkan lebih banyak tenaga. Hal ini setidaknya mengurangi pembakaran energi dalam tubuh yang dapat mengurangi cadangan energi di dalam tubuh ibu hamil. Tingkat aktifitas fisik seseorang berkaitan dengan jenis pekerjaannya. Beradasarkan uraian tersebut, oleh karena itu dalam penelitian ini ditemukan adanya ibu hamil yang memiliki pola makan kurang dan buruk namun penambahan berat badan baik. ${ }^{2}$

Dalam penelitian ini, adanya ibu hamil yang pola makannya baik namun mengalami penambahan berat badan yang kurang dapat diindikasikan bahwa makanan yang dikonsumsi ibu tidak adekuat terhadap kebutuhan tubuh ibu hamil pada kondisi tertentu. Konsumsi makanan yang adekuat untuk ibu hamil adalah yang jika dikonsumsi tiap harinya dapat memenuhi kebutuhan zat-zat gizi dalam kualitas maupun kuantitasnya. Artinya bahwa, adanya ibu yang hamil yang pola konsumsi dikategorikan baik namun mengalami penambahan berat badan yang kurang karena pada penelitian ini dikatehui bahwa seluruh responden/ibu hamil berada pada trimester II yang berarti bahwa semakin meningkatnya kebutuhan kalori/energi ibu hamil pada trimester-trimester akhir. Hal ini sesuai dengan penelitian Irawati dkk (2013) bahwa faktor yang berpengaruh pada pertambahan berat badan ibu hamil adalah indeks massa tubuh pra hamil serta konsumsi energi dan protein. ${ }^{36}$

\section{Hubungan Pola Makan berdasarkan Kadar Hb Ibu Hamil Trimester II}

Berdasarkan hasil penelitian yang dilakukan pada puskesmas pahandut diketahui jika pada tabel 5.13, 31 responden $(18,8 \%)$ dengan pola makan baik yang tidak anemia, sebanyak 12 
responden $(27,9 \%)$ dengan pola makan baik yang anemia. Sebanyak 8 orang $(17,4 \%)$ dengan pola mkan kurang dan pola makan buruk yang tidak anemia dan sebanyak 38 orang $(82,6 \%)$ dengan pola makan kurang \& buruk yang mengalami anemia. Berdasarkan presentase tersebut dapat dilihat jika pola makan juga berpengaruh terhadap kadar $\mathrm{Hb}$ pada ibu hamil. Rendahnya status gizi dan pola makan yang salah pada ibu hamil dapat menyebabkan anemia. ${ }^{1,2}$

Pola makan yang buruk menyebabkan rendahnya intake zat besi dalam tubuh, sehingga tubuh kekurangan zat gizi yang diperlukan untuk pembentukan hemoglobin. Sebaliknya, jika pola makan cukup atau baik maka tubuh tidak akan kekurangan zat gizi yang diperlukan untuk pembentukan $\mathrm{Hb}^{34}$ Berdasarkan hasil bivariat dengan menggunakan uji Chi-Square diperoleh hasil yang menunjukkan ada hubungan yang signifikan antara pola makan dengan kadar $\mathrm{Hb}$ pada ibu hamil trimester II di Puskesmas Pahandut, dengan nilai $p=<0,001$. Hal ini sesuai dengan penelitian Rizka Chibriyah (2017) bila terdapatnya hubungan pola makan dan aktivitas fisik terhadap kadar Hb. ${ }^{37}$

Pada tabel 5.1 diketahui jika sebagian ibu hamil berusia kurang dari 18 tahun dan lebih dari 35 tahun, dimana kehamilan dibawah usia 18 tahun dan diatas 35 tahun merupakan kehamilan beresiko tinggi. Hal ini sesuai dengan penelitian Indah Oktaviani, dkk (2017) dimana 2-4 lebih tinggi dibandingkan dengan kehamilan pada wanita yang cukup umur. Ibu hamil yang berumur 15-19 tahun memiliki resiko yang lebih tinggi mengalami anemia. Pada usia 21-35 tahun resiko gangguan kesehatan pada ibu hamil paling tendah yaitu sekitar 15\%. Selain itu apabila dilihat dari kematangan, wanita pada kelompok umur ini telah memiliki kematangan reproduksi, emosinal maupun aspek sosial. ${ }^{38}$

Pada tabel 5.5 diketahui jika banyak ibu hamil yang hamil lebih dari 2 kali, dimana semakin banyak jumlah paritas maka akan diikuti dengan meningkatnya kejadian anemia. paritas berhubungan dengan terjadinya anemia, karena semakin sering wanita melahirkan, lebih besar risiko kehilangan darah dan berdampak pada penurunan kadar hemoglobin. Seorang wanita yang sudah melahirkan lebih dari 2 kali, dan terjadi kehamilan lagi keadaan kesehatannya akan mulai menurun, sering mengalami anemia. Hal ini sesuai dengan penelitian Anasari (2012) dimana terdapat hubungan paritas dan anemia pada ibu hamil dengan jumlah anak lebih dari $2 .{ }^{39}$

Pada tabel 5.7 diketahui jika banyak ibu hamil adalah IRT, hal ini dapat diindikasikan bahwa aktifitas fisik yang dilakukan sebagai seorang IRT cenderung lebih rendah daripada ibu yang bekerja di luar rumah dengan kapasitas pekerjaan yang membutuhkan lebih banyak tenaga. Hal ini sesuai dengan penelitian Wardlaw G.M dan Anne M. (2009) dimana aktivitas fisik yang kurang menyebabkan metabolisme sel tubuh menurun sehingga menyebabkan metabolisme besi dalam tubuh menurun. Besi adalah zat komponen pembentuk $\mathrm{Hb}$, jika produksi besi menurun maka akan mempengaruhi pembentukan $\mathrm{Hb}$ yang akan berdampak pada menurunnya transport oksigen ke seluruh sel tubuh. ${ }^{40}$

Anemia dipengaruhi secara langsung oleh konsumsi makanan sehari-hari yang kurang mengandung asam folat dan zat besi, selain faktor infeksi sebagai pemicunya. Berdasarkan penelitian dilapangan, sebagian besar ibu hamil kurang mengonsumsi susu dan sayuran hijau, dimana berdasarkan pendapat Arisman (2009) 
bahwa jenis makanan yang banyak mengandung asam folat diantaranya adalah brokoli, sayuran hijau, ragi dan kacangkacangan. ${ }^{34}$

Saat hamil kebutuhan zat besi meningkat 2 kali lipat dari kebutuhan sebelum hamil. Hal ini terjadi karena selama hamil volume darah meningkat sampai 50\%, sehingga perlu lebih banyak zat besi untuk membentuk hemoglobin. Selain itu pertumbuhan janin dan plasenta yang sangat pesat, sehingga dibutuhkan suplemen berupa zat besi. Hal ini sesuai dengan penelitian Nurul Ulfiana Sahlan (2012) di kabupaten Barru kecamatan Tanete Rilau yaitu hasil uji hubungan asupan besi dengan kadar hemoglobin didapatkan nilai nilai $p=<0,001$ dan penelitian yang dilakukan oleh Debby Triwidyaastuti (2011) di kabupaten Takalar dengan nilai nilai $p=<0,001$ yang membuktikan bahwa terdapat hubungan yang bermakna antara asupan besi dengan kadar $\mathrm{Hb}$ ibu hamil. ${ }^{40,41}$

\section{KESIMPULAN}

Berdasarkan hasil penelitian yang telah dilakukan, dapat disimpulkan bahwa:

1. Ada hubungan pola makan dengan penambahan berat badan ibu hamil trimester II pada bulan Juni-Agustus di Puskesmas Pahandut tahun 2018 dengan nilai $p=<0,001$.

2. Ada hubungan pola makan dengan kadar Hemoglobin $(\mathrm{Hb})$ ibu hamil trimester II pada bulan Juni-Agustus di Puskesmas Pahandut tahun 2018 dengan nilai $p=<0,001$.

\section{DAFTAR PUSTAKA}

1. Dinas Kesehatan Kota Palangkaraya. Profil Kesehatan Kota Palangka Raya Tahun 2016. Available from URL : https://dinkes.palangkaraya.go.id/

download/. Accessed March 2, 2018.

2. Prawiharjo, Sarwono. Ilmu Kebidanan. Jakarta: Bina Pustaka 278-28 ; 2016.

3. Fatmah. Dalam Departemen Gizi (ed). Gizi dan Kesehatan Masyarakat. Jakarta: Departemen Gizi FK MUI ; 2012.

4. Supariasa. Pendidikan Dan Konsultasi Gizi. Jakarta : EGC ; 2012.

5. Sinsin, Lis. Seri Kesehatan Ibu dan Anak Masa Kehamilan dan Persalinan. Jakarta: Elex Media Kompitindo ; 2008.

6. WHO. Maternal Mortality: World Health Organization. Available from URL : http://www.who.int/gho/maternal_health/m ortality/maternal/en/index2.html. Accessed March 2, 2018.

7. Kemenkes RI. Buku Saku Pemantauan Status Gizi Tahun 2017. Available from URL http://sehatnegeriku.kemkes.go.id/wpcontent/uploads/2018/01/ Buku-SakuNasional-PSG-2017-Cetak-1.pdf . Accessed March 2, 2018.

8. Sinsin, Lis. Seri Kesehatan Ibu dan Anak Masa Kehamilan dan Persalinan. Jakarta: Elex Media Kompitindo ; 2008.

9. Balitbang Kemenkes RI.Riset Kesehatan Dasar : RISKESDAS. Jakarta: Balitbang Kemenkes RI ; 2013.

10. Febriani. Faktor-Faktor Resiko Yang Mempengaruhi Kematian Maternal. Jakarta: ECG ; 2007.

11. Prawita A, Susanti A.I, Sari P. Survei Intervensi Ibu Hamil Kurang Energi Kronik (KEK) di Kecamatan Jatinangor Tahun 2015. Semarang : Program Diploma Kebidanan, Fakultas Kedokteran Universitas Padjadjaran ; 2015 
12. Abidah S., Dode S, Ferial E.W. FaktorFaktor yang Mempengaruhi Terjadinya Anemia Pada Ibu Hamil di Rumah Sakit Ibu dan Anak Siti Fatimah Makasar ; 2013.

13. Departemen Kesehatan RI 2009. Pedoman Pelayanan Antenatal di Tingkat Pelayanan Dasar. Jakarta: DepkesRI ; 2009

14. Miko A, Dina PB. Hubungan Pola Makan Pagi Dengan Status Gizi Pada Mahasiswi Poltekkes Kemenkes Aceh. J AcTion : Aceh Nutrion Journal, November 2016 ; 1(2) : $83-87.2016$

15. Kementrian Kesehatan. Peraturan menteri kesehatan republik Indonesia Nomor 41 tahun 2014 Tentang Pedoman Gizi Seimbang. Jakarta ; 2014.

16. Fatimah,St.Hadju,V., Bahar,B., Abdullah,Z.(2011) Pola Konsumsi dan Kadar Hemoglobin pada Ibu Hamil di Kabupaten Maros, Sulawesi Selatan. Makara, Kesehatan, Vol.15,No. 1, Juni 2011: 31-36. 2011

17. Garib N, Parveen R. Energy and macronutrient intake and dietary pattern among school children in Bahrain. Nutr J 10:62. Available from URL : http://www.ncbi.nlm.nih.gov/pmc/articles/ PMC5104202 ; 2011 Accessed March 2, 2018.

18. Citerawati Y W, Sukati ND . Asesmen Gizi. Yogyakarta: Trans Medika; 2017.

19. Otten JJ, Meyers LD. Dietary reference intakes. The essential guide to nutrient requirements. National Academies Press; 2006.

20. Natalia P, Nasution E, Siagian A. Perilaku Konsumsi Gizi Seimbang Dan Status Gizi Pada Remaja Putri Di Sman 1 Tarutung Tahun 2012. Consumer Behavior and
Balanced Nutrition Nutritional Statusin Teenangers in the Year 2012 SMAN 1 Tarutung ; 2012.

21. Adikari A.M.N.T, Sivakanesan R,Wijesinghe D.G.N.GandLiyanage C. Assessmentof Nutritional Statusof PregnantWomenin a Rural Area in Sri Lanka. Tropical Agricultural Research Vol.27(2): 203 - 211; 2016.

22. Narasiang BR, Mavulu N, Kawegian S. Gambaran pola konsumsi makanan pada ibu hamil dikota Manado. J e-Biomedik (eBM), Juli-Desember 2016; 1(4) .

23. Hartriyanti, Y. \& Triyanti. Penilaian Status Gizi. In : Syafiq, A. Et All, Eds. Gizi Dan Kesehatan Masyarakat. Jakarta : Rajagrafindo Persada. 2007.

24. Aritonang, E. Kebutuhan Gizi Ibu Hamil, Bogor : IPB Press ; 2006.

25. Yeyeh,Lia. Asuhan Kebidanan IV (Patologi Kebidanan, Jakarta: Trans Info Media. 2010.113-117; 2010.

26. Departemen Kesehatan RI. Pedoman Pelayanan Antenatal di Tingkat Pelayanan Dasar. Jakarta: Depkes RI. 2007. 15-23; 2007.

27. Melku M, Assis Z, Alem M, \& Enawgaw B. Prevalence and Preditors of Maternal Anemia During Pregnancy in Gondar, North west Ethiopia: An Institusional Based Cross-Sectional Study. Hindawi Publishing Corporation, 2014, 9 ; 2014.

28. Sastroasmoro S. Ismael S. Dasar-dasar Metodologi Penelitian Klinis. Edisi 5. Jakarta: Sagung Seto. $95 ; 2014$.

29. Machfoedz, Ircham. Metodologi Penelitian Bidang Kesehatan, Keperawatan, Kebidanan, Kedokteran. Yogyakarta : Penerbit Fitramaya. 2009. 
30. Prasetyo, Bambang \& Lina Miftahul Jannah. Metode Penelitian Kuantitatif. Jakarta : Rajawali Pers. 2008.

31. Harti L. B , Kusumastuty I, Hariadi I. Hubungan Status Gizi dan Pola Makan terhadap Penambahan Berat Badan Ibu Hamil. Indonesian Journal Of Human Nutrion. 2016

32. Fajrina, Adiba. Skripsi. Hubungan Pertambahan Berat Badan dan Faktor Lain dengan Berat Badan Lahir. Depok: Fakultas Kesehatan Masyarakat Universitas Indonesia [Online: lib.ui.ac.id]. 2012. Accessed October, 12016

33. Retnaningsih, RAJ. Budiani. Hubungan Pengetahuan Ibu Hamil Tentang Gizi Dengan Status Gizi Ibu Hamil Trimester III Di Puskesmas Colomadu Ii Karanganyar. Program Div Kebidanan Fakultas Kedokteran Universitas Sebelas Maret Surakarta. 2010

34. Arisman. Gizi dalam daur kehidupan: buku ajar ilmu gizi. Jakarta; EGC. 2009

35. Istiany, Ruslianti. Gizi Terapan. Bandung: Remaja Rosdakarya. 2013

36. Irawati A, Rachmalina R. Indeks Massa Tubuh Ibu Pra Hamil sebagai Faktor Risiko Pertambahan Berat Badan Ibu Hamil di Kelurahan Kebun Kelapa dan Ciwaringin, Kecamatan Bogor Tengah, Kota Bogor. Jurnal Ekologi Kesehatan. 12(2): 117 127. 2013.

37. Chibriyah Rizka. Hubungan Pola Makan Dan Aktivitas Fisik Terhadap Kadar Hemoglobin Santriwati Pondok Pesantren Al-Munawwir Krapyak Bantul. 2017

38. Oktaviani I. ,Makalew L. , Solang S.D. Profil Haemoglobin Pada Ibu Hamil Dilihat Dari Beberapa Faktor Pendukung. Jurnal Ilmiah Bidan; ISSN : 2339-1731. 2016
39. Anasari T. Hubungan Paritas dan anemia dengan kejadian Inersia uteri pada ibu Bersalin di RSUD Prof. dr. Margono Soekarjo Purwokerto Tahun 2011. Jurnal Involusi Kebidanan. (2012);Vol. 2 No. 4:22 - 32. 2012

40. Wardlaw, G. M., \& Anne, M. Contemporary Nutrition Seventh Edition Mc Graw Hill Higher Education. New York: Wardlaw. 2009

41. Sahlan NU. Hubungan Pola Makan dengan Status Hemoglobin (Hb) Ibu Hamil di Kecamatan Tanete Rilau Kabupaten Barru Skripsi]. Makassar: Universitas Hasanuddin; 2012.

42. Triwidyastuty D. Faktor-Faktor yang Berhubungan Dengan Status Hemoglobin (Hb) Ibu Hamil di Kelurahan Manongkoki Kecamatan Polongbangkeng Utara Kabu 